\title{
Praise for Globalization
}

"Not a week goes past without a new book on globalization; diminishing returns have long set in. But this collection, bringing together perspectives from anthropology and marrying them beautifully with history and economics, offers unique and invaluable insights. No serious student of globalization can afford to ignore it."

\section{Jagdish Bhagwati, Professor, Columbia University,} author of Free Trade Today

"At last a book which assesses the impact of globalization on the neglected but crucial topic of culture and education. What does it mean to be young in a world which is increasingly connected through technology, trade, and population movements but where the gulf between rich and poor, between good schools and bad, or between cultures is apparently growing? The product of collaboration among distinguished scholars, this impressive collection provides much-needed insights, analysis, and answers."

Margaret MacMillan, Provost, Trinity College,

Toronto, Ontario

"A brilliant collection of essays about the urgency of rethinking educational change, both its challenges and opportunities. In a world of increasingly coordinated markets and rising populations of migrants, state educational policies strain to develop the philosophical and material resources that can address cultural and economic differences without, one hopes, confusing equality with homogeneity. This book is a major contribution toward wresting democratic futures from an uneven present."

Doris Sommer, Ira Jewell Williams Jr. Professor of

Romance Languages and Literature, Harvard University

"A book of serious scholarship written by leading authorities in their fields. Although each chapter stands on its own, the whole book adds up to an account of the impact of globalization on education, which is much greater than the sum of its parts."

George Walker, Director General, International Baccalaureate Organization

"This book comprehensively explores the challenges that globalization poses to educators. The fate and future of the planet's children rest on the ability of education to meet those challenges. The contributors, experienced educators themselves, have thought freshly and deeply on the cultural implications of the globalizing process."

Arthur Schlesinger, author of A Thousand Days:

John F. Kennedy in the White House 
"This book is unlike any other because it marries what we know and think about globalization to a fascinating account of the development of young people. The authors proclaim the message that globalization is a powerful tool for enlarging human capacity but that this potential can be realized only if our techniques and systems of education change drastically. It's a message which all those who care about the future of our species should heed."

Lord Skidelsky, founder and Chairman, Centre for Global Studies, Warwick University 
GLOBALIZATION 
This page intentionally left blank 


\section{GLOBALIZATION}

CULTURE AND EDUCATION

IN THE NEW MILLENNIUM

Edited by

Marcelo M. Suárez-Orozco

and

Desirée Baolian Qin-Hilliard

UNIVERSITY OF CALIFORNIA PRESS

BERKELEY LOS ANGELES LONDON

THE ROSS INSTITUTE

( 
Chapter io, "How Education Changes:

Considerations of History, Science, and

Values," is () 2004 by Howard Gardner.

University of California Press

Berkeley and Los Angeles, California

University of California Press, Ltd.

London, England

(C) 2004 by the Regents of the University of California

Library of Congress Cataloging-in-Publication Data

Globalization : culture and education in the new millennium / edited by Marcelo M. Suárez-Orozco and Desirée Baolian Qin-Hilliard.

p. $\quad \mathrm{cm}$.

"Published in association with the Ross Institute."

Includes bibliographical references and index.

ISBN 0-520-24I 23-I (cloth : alk. paper) -

ISBN 0-520-24I 25-8 (pbk. : alk. paper)

I. Globalization. 2. Education. 3. Culture.

I. Suárez-Orozco, Marcelo M., I956- II. Qin-

Hilliard, Desirée Baolian, I972-

JZI3I8.G57925 2004

$303.48^{\prime} 2$ - de22

2003061084

Manufactured in the United States of America

$\begin{array}{lllllll}\text { I0 } & 09 & 08 & 07 & 06 & 05 & 04\end{array}$

I0 $\quad 9 \begin{array}{lllllllll} & 8 & 7 & 6 & 5 & 4 & 3 & 2 & \text { I }\end{array}$

The paper used in this publication meets the minimum requirements of ANSI/NISO Z39.48-I992(R I997)

(Permanence of Paper). $\infty$ 
For Courtney Ross-Holst 
This page intentionally left blank 